\title{
PENGEMBANGAN E-LEARNING MATERI HUKUM NEWTON UNTUK MENINGKATKAN KETERAMPILAN BERPIKIR KRITIS SISWA SEKOLAH MENENGAH ATAS
}

\author{
Septania Pratiwi, Ketang Wiyono, Zulherman \\ Prodi Pendidikan Fisika, FKIP, Universitas Sriwijaya \\ Email: septaniaprtw98@gmail.com
}

Diterima: 26 April 2020 Disetujui: 30 Juli 2020

\begin{abstract}
Abstrak
Penelitian ini bertujuan untuk menghasilkan e-learning fisika materi hukum Newton untuk mengembangkan keterampilan berpikir kritis siswa Sekolah Menengah Atas yang memiliki tingkat validitas tinggi dan praktis. Model Penelitian pengembangan yang digunakan adalah model Rowntree. Tahap evaluasi yang digunakan adalah evaluasi formatif Tessmer yang terdiri dari empat tahap: self evaluation, expert review, one-to-one evaluation, dan small group evaluation. Teknik pengumpulan data menggunakan walkthrough dan angket. Tingkat validitas e-learning ini dinilai masing-masing oleh tiga ahli, yakni dalam aspek materi, aspek desain pembelajaran, dan aspek e-learning serta analisis data menggunakan indeks Aiken $\mathrm{V}$ untuk mengetahui kesepakatan dari para ahli. Hasil pengembangan e-learning menunjukkan bahwa media yang dihasilkan layak untuk digunakan dalam pembelajaran fisika. Hal ini dapat dilihat dari nilai indeks Aiken V sebesar 0,94 dengan kategori tingkat validitas tinggi. Sedangkan pada tahap one-to-one evaluation dan small group evaluation diperoleh hasil rata-rata sebesar $81,84 \%$ dan $90,00 \%$ serta termasuk kategori sangat praktis.
\end{abstract}

Kata Kunci: : E-learning, Keterampilan Berpikir Kritis, Hukum Newton.

\begin{abstract}
The study aims to produce the e-learning physics of Newton's legal material to develop the critical thinking skills of high school students who have higher and practical validity rates. The model of development research used is Rowntree models. The evaluation phase used is Tessmer's formative evaluation consisting of four phases: Self evaluation, expert review, one-toone evaluation, and small group evaluation. Data collection techniques using walkthroughs and polls. This level of e-learning validity is judged by three experts, namely in material aspects, learning design aspects, and e-learning aspects as well as data analysis using the Aiken V Index to determine the consensus of the experts. The results of the development of e-learning indicate that the resulting media is suitable for use in learning physics. This can be seen from the Aiken V index value of 0.94 with a high level of validity category. Meanwhile, one-to-one evaluation and small group evaluation are obtained by average result of $81.84 \%$ and $90.00 \%$ and also includes very practical category.
\end{abstract}

Keywords: E-Learning, Critical Thinking Skills, Newton's Law. 
Pratiwi., Wiyono., Zulherman. - Pengembangan E-Learning ...

\section{PENDAHULUAN}

Pendidikan saat ini berada di masa pengetahuan (knowledge age) dengan percepatan peningkatan pengetahuan yang luar biasa. Di abad ke 21 ini, pendidikan menjadi semakin penting untuk menjamin siswa memiliki keterampilan belajar dan berinovasi, keterampilan menggunakan teknologi dan media informasi, serta dapat bekerja, dan bertahan dengan menggunakan keterampilan untuk hidup (life skills) (Arifin, 2017).

Pendidikan ialah suatu proses kegiatan yang secara sistematis diarahkan kepada suatu tujuan proses pembelajaran yang optimal. Untuk mewujudkan hasil yang optimal, siswa dilibatkan secara aktif dalam proses pembelajaran (Yusuf, 2016).

Maka dari itu pendidikan diharapkan mampu menjadikan peserta didik dalam mencapai proses pendewasaan dan mandiri dalam kehidupannya

Kemajuan ilmu pengetahuan dan teknologi telah berpengaruh terhadap penggunaan alat-alat bantu mengajar di sekolah-sekolah dan lembagalembaga pendidikan lainnya
(Aththibby \& Salim, 2015). Kemajuan teknologi menawarkan berbagai kemudahan bagi manusia untuk memperoleh informasi dalam waktu singkat. Pemenuhan kebutuhan manusia akan informasi menjadi lebih cepat dengan hadirnya internet. Internet sebagai media pembelajaran menjadi salah satu pilihan yang mendukung kegiatan pembelajaran (Herayanti et al., 2015).

Salah satu contoh dalam perkembangan teknologi di bidang pendidikan yaitu e-learning. Elearning merupakan kependekan dari electronic learning. E-learning merupakan salah satu media elektronik yang menggunakan pemanfaatan internet untuk memperoleh sumber informasi yang sangat luas dan aktual. Berbagai aplikasi teknologi informasi dan komunikasi sudah tersedia dalam bentuk open source dan dapat di download secara gratis (Yusuf, 2016). Dalam proses penyelenggaraan E- learning, maka dibutuhkan sebuah Learning Management System (LMS). 
Pratiwi., Wiyono., Zulherman. - Pengembangan E-Learning ...

Penggunaan E-learning tidak terlepas dari adanya blended learning. Blended learning atau juga dikenal sebagai Hybrid Learning adalah model pembelajaran yang menggabungkan berbagai model presentasi di kelas dengan pembelajaran online ( $\mathrm{Wu}$, Tennyson, \& Hsia., 2010). Fisika termasuk pelajaran yang memberikan pengetahuan tentang alam semesta agar melatih cara berpikir dan bernalar, melalui kemampuan penalaran seseorang yang terus dilatih membuat semakin berkembang, maka orang tersebut akan bertambah pengetahuan dan daya pikirnya (Supardi et al., 2015). Pembelajaran fisika mengharuskan pendidik untuk dapat memvisualisasi berbagai cara yang tepat untuk memberikan pemahaman kepada peserta didik. Konsep fisika yang bersifat abstrak dan materinya cukup luas, maka dibutuhkan metode yang tepat untuk memvisualisasikannya agar terhindar dari misksonsepsi (Diani et al., 2018). Siswa merasa fisika merupakan pelajaran sulit serta penuh dengan rumus-rumus, banyaknya materi pelajaran yang harus dihafalkan, kurangnya motivasi dari dalam diri siswa untuk mempelajari fisika, serta ketidaktepatan model, metode, dan media pembelajaran yang digunakan oleh guru, sehingga kegiatan pembelajaran terasa jenuh dan membosankan (Gagese, Wahyono, \& Kendek., 2018).

Strategi pembelajaran yang dibutuhkan dimana guru bertindak sebagai fasilitator dan saat pembelajaran berlangsung, diberikan aneka sumber belajar yang relevan, sehingga mampu menambah pengetahuan, membuka wawasan dan tumbuhnya keterampilan berpikir kritis serta peningkatan hasil belajar siswa. Pesatnya perkembangan teknologi disekitar, membuat seseorang dituntut untuk memiliki kemampuan berpikir tingkat tinggi (Ardianto et al., 2019).

Menurut Krulik dan Rudnick dalam (Tanjung et al., 2018) kemampuan berpikir kritis dirasakan penting karena kemampuan berpikir kritis dapat mendukung siswa dalam pengambilan keputusan, penilaian dan pemecahan masalah. Dengan kemampuan ini siswa dapat 
Pratiwi., Wiyono., Zulherman. - Pengembangan E-Learning ...

mempelajari masalah secara sistematis, merumuskan pertanyaan inovatif dan merancang solusi orisinal.

Berdasarkan survey prapenelitian melalui kuisoner angket, dengan jumlah responen 88 siswa yang tersebar ke SMA IPA di Sumatera Selatan maupun di luar Sumatera Selatan diperoleh data berupa $95,5 \%$ siswa selalu menggunakan handphone untuk beraktivitas sehari-hari, tetapi hanya $12,5 \%$ siswa yang menggunakan handphone untuk aplikasi pembelajaran. $14,8 \%$ siswa tidak tahu apa itu e-learning, dan 52,3\% siswa belum pernah belajar menggunakan e-learning di sekolah.

Selain menggunakan angket, peneliti juga melakukan wawancara dengan salah satu guru fisika di SMA Negeri 3 Palembang.

Hasil wawancara tersebut menyatakan bahwa pembelajaran fisika itu termasuk pembelajaran yang rumit, dimana hasil belajar siswa kelas $X$ IPA di SMA Negeri 3 Palembang kebanyak- kan masih di bawah rata-rata khususnya untuk pelajaran hukum Newton.
Peneliti menyadari dengan data dan hasil wawancara tersebut penting dikembangkannya e-learning sebagai inovasi sistem pembelajaran berbasis internet yang menarik, mudah diakses dan waktu yang felksibel. Sejalan dengan hal tersebut, berdasarkan data survey kebutuhan diperoleh data sebesar 96\% siswa merasa perlu adanya pembelajaran e-learning pada pelajaran fisika di sekolah.

\section{METODE}

Penelitian ini merupakan penelitian pengembangan atau (Research and dvelopment) dengan model Rowntree yang memilik tiga tahap pelaksaaan yaitu tahap perencanaan, tahap pengembangan dan tahap evaluasi.

Pada tahapan awal yaitu tahap perencanaan yang terbagi menjadi analisis kebutuhan dan perumusan tujuan pembelajaran yang berdasarkan silabus dan RPP materi terkait. Tahap pengembangan terbagi menjadi pengembangan topik, penyusunan draf, dan produksi prototipe dari produk yang akan digunakan yaitu berupa e-learning. 
Pratiwi., Wiyono., Zulherman. - Pengembangan E-Learning ...

Pada tahap evaluasi, peneliti indikator berpikir kritis, yaitu menggunakan model evaluasi berupa: (1) merumuskan pertanyaan formatif Tessmer yang terdiri dari (berfokus pada masalah), (2) empat tahap yaitu: (1) self menganalisis agumen, (3) menanya evaluation; dan menjawab pertanyaan,

(2) expert review; (3) one-to-one melakukan observasi, serta

evaluation; (4) small group evaluation (Apriani., dkk, 2016).

Penelitian ini dilakukan pada semester genap tahun ajaran 2019/2020 di SMA Negeri 3 Palembang. Penelitian ini dilakukan untuk mengembangkan keterampilan berpikir kritis siswa sekolah penggunaan teknologi (Ennis, 2011).

Teknik pengumpulan data yang digunakan adalah teknik walkthrough dan angket. Lembar validasi yang diberikan berupa bentuk skala likert yang dibuat dalam bentuk tabel checklist dengan lima kategori jawaban seperti Tabel 1 .

menegah atas mengacu pada

Tabel 1. Kategori Nilai Validasi

\begin{tabular}{cc}
\hline Kategori Jawaban Skor Pernyataan \\
\hline Sangat sesuai & 5 \\
Sesuai & 4 \\
Cukup sesuai & 3 \\
Kurang sesuai & 2 \\
Tidak sesuai & 1 \\
\hline
\end{tabular}

Selanjutnya dilakukan analisis data menggunakan indeks validitas Aiken V, hal ini dikarenakan validasi dilakukan oleh tiga ahli yang masing-masing mencakup aspek materi, desain pembelajaran dan elearning.

Untuk mengetahui kesepakatan ahli, maka dapat digunakan indeks validitas yang diusulkan oleh Aiken (Ningsih et al., 2018). Berikut rumus indeks Aiken V:

$$
V=\frac{\sum s}{n(c-1)}
$$

Dimana V adalah indeks kesepakatan ahli mengenai validitas isi butir; $\mathrm{s}$ adalah skor yang ditetapkan ahli dikurangi skor 
Pratiwi., Wiyono., Zulherman. - Pengembangan E-Learning ...

terendah dalam kategori yang dengan lima kategori jawaban seperti digunakan $(s=r-l 0)$; dengan $r$ adalah skor kategori pilihan ahli dan l0 adalah skor terendah dalam kategori penilaian); $\mathrm{n}$ adalah adalah banyaknya ahli; dan c adalah banyaknya kategori yang dapat dipilih oleh ahli. pada Tabel 3 .

Kemudian dicari persentase hasil one to one evaluation dan small group (HEOS) yang berpedoman pada Wiyono (2015) untuk melihat tingkat kepraktisan e-learning dengan rumus:

Tingkat kevalidan dari e- $\quad H E O S=\frac{\text { Skor raihan angket }}{\text { Skor maksimal angket }} \times 100 \%$ learning dilihat dari persentase Indeks Aiken $\mathrm{V}$, sebagaimana terlihat pada Tabel 2.

Sedangkan nilai angket yang diberikan berbentuk tabel checklist

Persentase HEOS ini kemudian dicocokkan dengan tabel tingkat kepraktisan yang disajikan pada Tabel 4.

Tabel 2. Kategori Hasil Validasi Ahli

\begin{tabular}{cc}
\hline Kategori & Persentase \\
\hline Validitas Tinggi & $\mathrm{V}>0.8$ \\
Validitas Sedang & $0.4<\mathrm{V} \leq 0.8$ \\
Validias Kurang & $\mathrm{V}<0.4$ \\
\hline
\end{tabular}

Tabel 3. Kategori Nilai Angket

\begin{tabular}{cc}
\hline Kategori Jawaban & Skor Pernyataan \\
\hline Sangat sesuai & 5 \\
Sesuai & 4 \\
Cukup sesuai & 3 \\
Kurang sesuai & 2 \\
Tidak sesuai & 1 \\
\hline
\end{tabular}

Sumber: (Sugiyono, 2016) 
Pratiwi., Wiyono., Zulherman. - Pengembangan E-Learning ...

Tabel 4. Kategori Hasil Nilai Angket

\begin{tabular}{cc}
\hline Persentase $(\%)$ & Kategori \\
\hline $86 \leq H E O S \leq 100$ & Sangat Praktis \\
$70 \leq H E O S \leq 86$ & Praktis \\
$56 \leq H E O S \leq 70$ & Kurang Praktis \\
$H E O S \leq 56$ & Tidak Praktis \\
\hline \multicolumn{2}{c}{ Sumber: (Wiyono, 2015) }
\end{tabular}

\section{HASIL DAN PEMBAHASAN}

Penelitian ini dilakukan dengan tiga tahap yaitu tahap perencanaaan, tahap pengembangan dan tahap evaluasi, peneliti menggunakan tahap evaluasi formatif Tessmer yang terdiri dari empat tahap, yaitu self evaluation, expert review, one to one evaluation, dan small group evaluation. Pada tahap perencanaan dilakukan analisis kebutuhan dan rumusan tujuan pembelajaran. Pada analisis kebutuhan dilakukan analisis terhadap produk, peserta didik dan materi pada e- learning.

Pada tahap pengembangan diawali dengan melakukan pengembangan topik, penyusunan draft, dan produksi prototipe. Pada tahap pengembangan topik dimulai dengan penyusunan materi pembelajaran yang sesuai dengan tujuan pembelajaran yang akan dicapai siswa.

Tahap penyusunan draft dilakukan dengan membuat rancangan awal e- learning materi hukum newton lalu dilanjutkan dengan membuat storyboard dan flowchart. Rancangan awal flowchart mendeskripsikan fitur- fitur yang terdapat dalam e-learning yang dapat dilihat pada gambar 1 .

Pada tahap produksi prototipe elearning materi hukum newton ini dikembangkan dengan menggunakan aplikasi schoology. Schoology adalah situs yang menggabungkan antara jejaring sosial dan LMS, sehingga dengan Schoology kita dapat berinteraksi sosial sekaligus belajar dengan materi yang menarik minat siswa dengan berbagai macam fitur. 
Pratiwi., Wiyono., Zulherman. - Pengembangan E-Learning ...

Adapun fitur-fitur yang dimiliki Schoology adalah: (1) Courses (Kursus), yaitu fasilitas untuk membuat kelas mata pelajaran; (2) Groups (Kelompok), yaitu fasilitas untuk membuat kelompok;
Resources (Sumber Belajar), dalam fitur resource dapat menambahkan materi yaitu berupa : assignment, test/quiz, file/link, discussion, page dan media album.

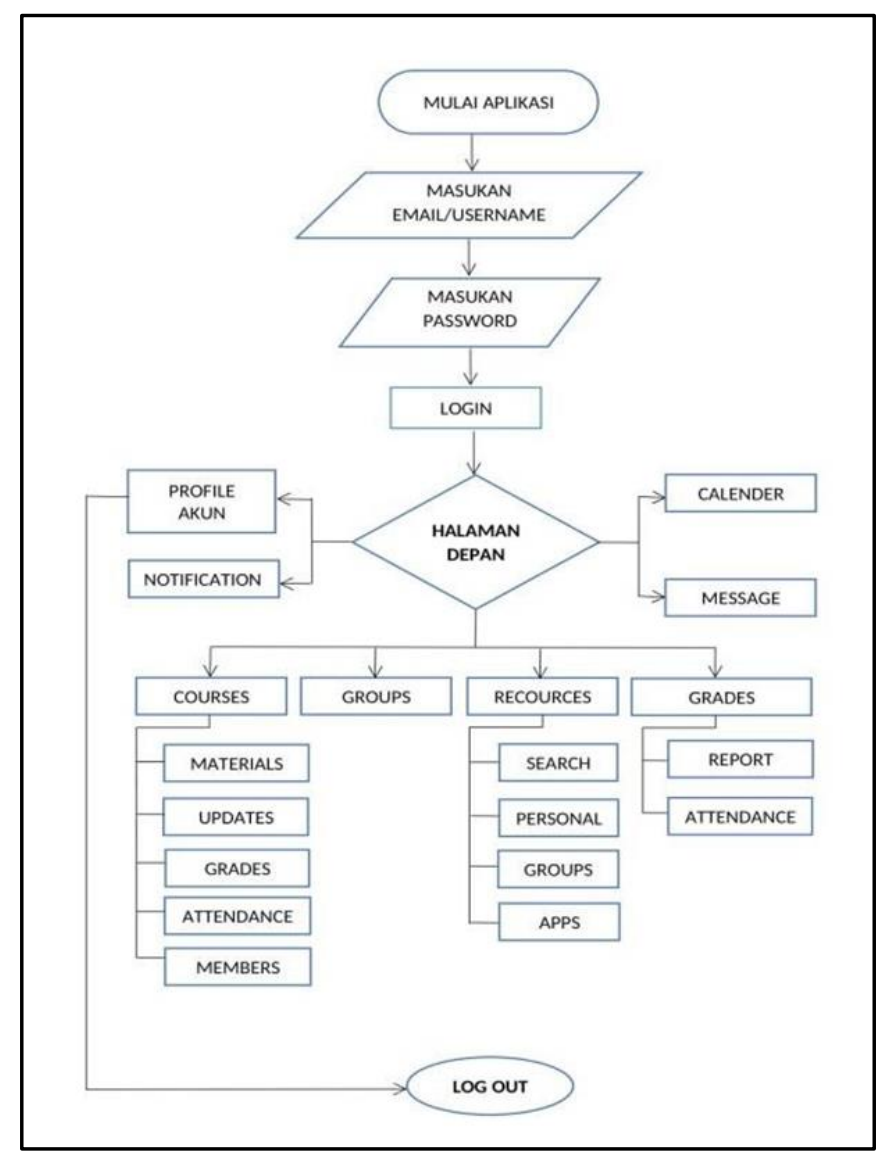

Gambar 1. Flowchart E-Learning

Schoology memiliki tiga pilihan pengguna untuk mengaksesnya, yaitu pengguna sebagai guru (teacher), siswa (student), dan orangtua (parent).
Selain itu, e-learning pada schoology ini didalamnya disertai dengan gambar, video, link, virtual laboratory dan simulasi. Hal ini dapat membantu siswa dalam memahami konsep fisika, membantu 
Pratiwi., Wiyono., Zulherman. - Pengembangan E-Learning ...

siswa untuk tidak bosan dalam belajar fisika, serta terdapat forum diskusi yang dapat membantu siswa berinteraksi secara digital baik antarsesama siswa maupun siswa dengan guru.

Fasilitas dari schoology yang sangat mendukung untuk penulisan teks, rumus dan gambar serta dapat memfasilitasi penilaian pada pembelajaran fisika. Berikut merupakan tampilan awal dari elearning materi hukum newton pada aplikasi schoology dapat dilihat pada gambar 2.

Peneliti memilih aplikasi schoology dikarenakan schoology memiliki beragam fitur lengkap mulai dari daftar kehadiran siswa, raport online, diskusi online, serta kuis/PR.

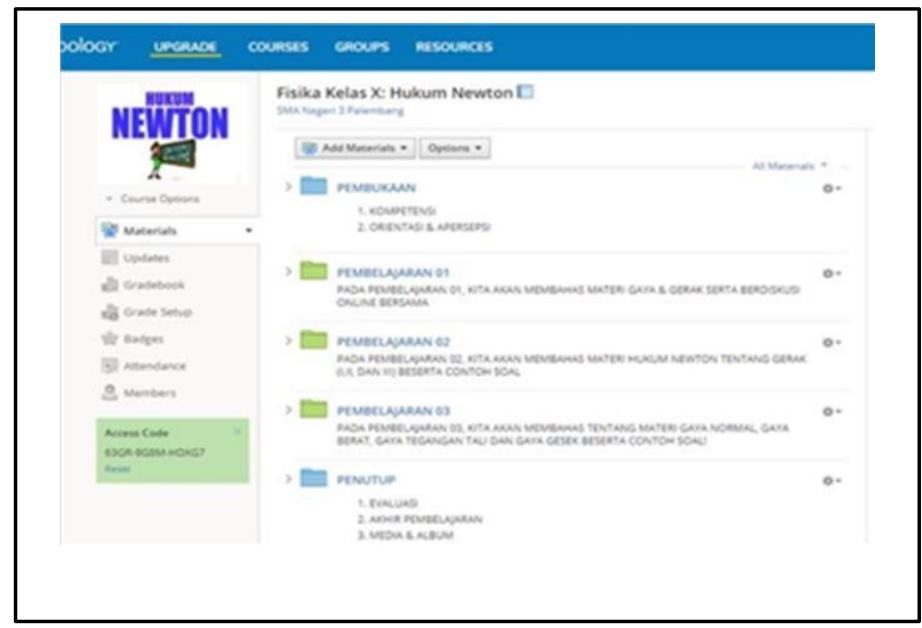

Gambar 2. Tampilan awal e learning

Pembelajaran blended dapat bahwa seluruh informasi dapat diterapkan saat menggunakan dengan mudah diakses schoology, dimana terdapat dua menggunakan internet. Blended sistem pembelajaran yaitu langsung learning memudahkan siswa untuk (tatap muka) dan secara online. melakukan aktivitas belajar baik di Pendekatan blended learning sangat kelas maupun di luar kelas sejalan sejalan dengan kebutuhan para dengan materi dibutuhkan. Jika pelajar milenial sekarang, mengingat belum paham akan materi yang 
Pratiwi., Wiyono., Zulherman. - Pengembangan E-Learning ...

diberikan guru saat di kelas, para siswa dapat kembali mengulang materi tersebut di e-learning schoology.

Pada tahap evaluasi Tessmer, tahapan pertama adalah self evaluation atau evaluasi diri, dimana peneliti menilai sendiri dengan melakukan pengecekan terhadap hasil e-learning yang dikembangkan dengan dibimbing oleh dosen pembimbing skripsi. Produk berupa e-learning yang telah di revisi pada tahap self evaluation selanjutnya divalidasi oleh tujuh validator pada tahap expert review.

Tahap ini dilakukan untuk mengetahui tingkat validitas dari elearning yang dibuat. Disini peneliti memohon bantuan kepada tujuh ahli sebagai validator pada aspek materi, aspek e-learning dan aspek desain pembelajaran. Ketujuh validator tersebut terdiri dari tiga dosen pendidikan fisika FKIP UNSRI, dua guru fisika dan dua guru TIK pada dua sekolah yang berbeda yaitu SMA Negeri 3 Palembang dan SMAN 1 Indralaya Utara.

Pada tahap expert review ini ketiga validator diberikan lembar angket masing-masing sesuai aspeknya, yaitu aspek materi, aspek e-learning dan aspek desain pembelajaran. Lembar angket yang diberikan berbentuk skala likert yang dibuat dalam bentuk tabel checklist dengan lima kategori jawaban berdasarkan Sugiyono (2016).

Adapun hasil dari validasi ahli terhadap materi hukum newton yang meliputi aspek materi, aspek elearning, dan aspek desain pembelajaran dapat dilihat pada tabel 5.

Tabel 5. Hasil Penilaian Validator Pada Tahap Expert Review

\begin{tabular}{lc}
\hline \multicolumn{1}{c}{ Aspek } & $\begin{array}{c}\text { Nilai Rerata dan } \\
\text { Kategori }\end{array}$ \\
\hline Materi & 0,94 \\
\hline E-Learning & 0,93 \\
\hline Desain Pembelajaran & 0,96 \\
\hline Rata-Rata & 0,94 \\
\hline
\end{tabular}


Pratiwi., Wiyono., Zulherman. - Pengembangan E-Learning ...

Perolehan rerata total skor mewakili siswa yang tergolong validasi menggunakan indeks Aiken kelompok tinggi, sedang dan rendah $\mathrm{V}$ pada aspek materi rerata skor sebesar 0,94 dan termasuk kategori validitas tinggi, pada aspek desain pembelajaran rerata skor sebesar 0,96 dan termasuk kategori validitas tinggi, dan pada aspek e-learning rerata skor sebesar $\mathrm{V}$ 0,93 dengan kategori validasi tinggi. Berdasarkan hasil Tabel 2 maka $e$ - learning materi hukum newton termasuk kedalam kategori yang memiliki tingkat validitas tinggi dan layak untuk diujicobakan. Selain memberikan penilaian secara numerik, validator ahli juga memberikan komentar dan saran terkait dari e- learning yang dikembangkan untuk perbaikan. Selanjutnya yaitu tahap one-to-one evaluation, validasi dilakukan oleh tiga orang siswa di kelas digital $\mathrm{X}$ IPA 1 di SMA Negeri 3 Palembang. yang disarankan oleh guru mata pelajaran fisika. Sebelum mengisi angket, peneliti menjelaskan lebih dulu mengenai e-learning hukum newton pada schoology beserta fiturnya. Setelah itu, siswa tersebut diberikan angket terkait elearning schoology yang berupa skala likert berbentuk tabel checklist, kemudian hasilnya diolah dengan mencari persentase hasil oneto-one evalation dan small group (HEOS) yang berpedoman pada Wiyono (2015. Setelah dihitung sesuaikan persentase hasil validasi dengan Tabel 4 tentang kategori hasil nilai angket.

Tabel 6 menunjukkan kategori hasil nilai angket, diperoleh hasil tanggapan siswa pada tahap one- toone evaluation sebesar $81,84 \%$ dan Tiga orang siswa yang dipilih termasuk kategori praktis.

Tabel 6. Hasil Penilaian Angket Tahap one-to-one evaluation

\begin{tabular}{cc}
\hline Nama Siswa & Persentase (\%) \\
\hline KCE & 85,2 \\
DE & 82,03 \\
SN & 78,30 \\
Rerata & 81,84
\end{tabular}


Pratiwi., Wiyono., Zulherman. - Pengembangan E-Learning ...

Tahap selanjutnya yaitu tahap uji coba small group evaluation yang dilakukan setelah revisi pada tahap expert review dan tahap one-to-one evaluation. Pada tahap ini peneliti memilih sembilan siswa dari kelas yang sama yaitu X IPA 1 di SMA Negeri 3 Palembang dengan siswa yang berbeda pada tahap sebelumnya. Kesembilan siswa tersebut termasuk dalam tiga siswa dengan kategori tinggi, tiga siwa dengan kategori sedang dan tiga siswa dengan kategori rendah berdasarkan saran guru mata pelajaran fisika.

Sebelum melakukan kegiatan pembelajaran peneliti menjelaskan bagaimana pengoperasian e-learning schoology pada siswa. Setelah itu siswa melakukan pembelajaran dan diakhiri dengan mengisi lembar angket terkait e-learning schoology. Angket berupa skala likert berbentuk tabel checklist, kemudian hasilnya diolah dengan mencari persentase hasil one-to-one evaluation dan small group evaluation (HEOS) yang berpedoman pada Wiyono (2015). Setelah dihitung sesuaikan persentase hasil validasi dengan
Tabel 4 tentang kategori hasil nilai angket.

\section{KESIMPULAN DAN SARAN}

\section{Kesimpulan}

Berdasarkan penelitian yang telah dilakukan bahwa pengembangan e-learning pada materi hukum newton untuk mengembangkan keterampilan berpikir kritis siswa SMA telah memiliki tingkat validitas tinggi dan sangat praktis dengan perolehan data sebesar 0,94 untuk tahap expert review, sebesar $81,84 \%$ untuk tahap one-to-one evaluation dan 90,00\% untuk tahap small group evaluation.

\section{Saran}

Sebagai tindak lanjut dari penelitan yang telah dilakukan, maka perlu di kembangkan lagi e-learning dengan materi yang berbeda khususnya pada

pelajaran fisika, mengingat pembelajaran sekarang sudah banyak terintegrasi dengan teknologi. Sekolah juga harus menyediakan jaringan internet yang memadai untuk mendukung pembelajaran elearning. 
Pratiwi., Wiyono., Zulherman. - Pengembangan E-Learning ...

\section{DAFTAR PUSTAKA}

Apriani, H., Murniati, M., \& Pasaribu,

Pengembangan

(2016).

dinamika rotasi dan

kesetimbangan benda tegar

berbasis kontekstual kelas XI

IPA SMA. Jurnal Inovasi dan

Pembelajaran Fisika. 3(2): 1-6.

Ardianto., Ertikanto, C., \& Nyeneng,

I.D.P., (2019).Pengaruh

Keterampilan Berpikir Kritis

Melalui Pembelajaran Berbasis

Aneka Sumber Belajar

Terhadap Hasil Belajar Fisika

Siswa. Jurnal Pendidikan

Fisika Universitas

Muhammadiyah Metro. 7(1): 28-38.

Arifin, Z. (2017). Mengembangkan Instrumen Pengukur Critical Thinking Skills Siswa pada Pembelajaran Matematika Abad 21. Theorems, 1(2), 92100.

Aththibby, A. R., \& Salim, M. B. (2015). Pengembangan Media Pembelajaran Fisika Berbasis Animasi Flash Topik Bahasan Usaha dan Energi. Jurnal Pendidikan Fisika Universitas Muhammadiyah Metro, 3(2), 25-33.

Diani, R., Latifah, S., Anggraeni, Y. M., \& Fujiani, D. (2018). Physics Learning Based on Virtual Laboratory to Remediate Misconception in Fluid Material. Tadris: Jurnal Keguruan dan Ilmu Tarbiyah, 3(2), 167.

Ennis, R.H. (2011). The Nature of Critical Thinking: An Outline of Critical Thinking Dispositions and Abilities [Online].
Gagese, N., Wahyono, U., \& Kendek, Y. (2018). Pengembangan Mobile Learning Berbasis Android pada Materi Listrik Dinamis. JPFT (Jurnal Pendidikan Fisika Tadulako, 6(1), 44-49.

Herayanti, L., Fuaddunnazmi, M., \& Habibi. (2015). Pengembangan Media Pembelajaran berbasis Moodle Pada Mata Kuliah Fisika Dasar. Jurnal Pendidikan Fisika Dan Teknologi, 1(3), 205-209.

Kurniasih, A. W. (2012). Scaffolding sebagai Alternatif

Upaya Meningkatkan

Kemampuan Berpikir Kritis Matematika. Kreano: Jurnal Matematika Kreatif-Inovatif, 3(2), 113-124.

Ningsih, D. R., Ramalis, T. R., \& Purwana, U. (2018). Pengembangan Tes Keterampilan Berpikir Kritis Berdasarkan Analisis Teori Respon Butir. WaPFi (Wahana Pendidikan Fisika), 3(2), 45.

Sugiyono. (2016). Metode Penelitian \& Pengembangan Research and Development. Bandung: Alfabeta.

Supardi, S. U., Leonard, L., Suhendri, H., \& Rismurdiyati, R. (2015). Pengaruh media pembelajaran dan minat belajar terhadap hasil belajar fisika. Formatif: Jurnal Ilmiah Pendidikan MIPA, 2(1).

Tanjung, H. S., \& Nababan, S. A. (2018). Pengembangan Perangkat Pembelajaran Matematika Berorientasi Model Pembelajaran Berbasis Masalah ( PBM ) Untuk Meningkatkan Kemampuan Berpikir Kritis 
Pratiwi., Wiyono., Zulherman. - Pengembangan E-Learning ...

Siswa SMA Se-Kuala Nagan Raya Aceh. Genta Mulia: Jurnal Ilmiah Pendidikan, 9(2), $56-70$.

Wiyono, K. (2015). Pengembangan model pembelajaran fisika berbasis ICT pada implementasi kurikulum 2013. Jurnal Inovasi dan Pembelajaran Fisika, 2(2), 123-131.
Wu, J. H., Tennyson, R. D., \& Hsia, T. L. (2010). A study of student satisfaction in a blended elearning system environment. Computers \& Education, 55(1), 155-164.

Yusuf, A. R. (2016). Penerapan ELearning Sebagai Penunjang Pembelajaran Berbasis Kurikulum 2013. In Seminar Nasional Telekomunikasi dan Informatika. 